論文

$$
\text { ステレオマッチングによるストレッチ・ゾーンの解明* }
$$

滳内良雄**

\title{
Analysis of Stretched Zone by Means of Stereo Matching Method
}

by

\author{
Yoshio KITSUNAI
}

(Research Institute of Industrial Safety, Kiyose)

\begin{abstract}
Stereo measurements of the stretched region in the fracture toughness specimens used for Jintegral tests were carried out by examining the shape and the angle to the crack plane with a scanning electron microscope.

It was found that the shape of the stretched zone consisted of two portions, one of which forms a gradual slope and the other a steep slope to the plane of pre-crack. The scatter of the measured values of the angle of the stretched zone to the crack plane was very large, ranging from 10 to 48 degrees. However, in many cases the angle was about 33 degrees. As the result of stereo matching observations, unsymmetrical profiles of the stretched zone were often found even though the widths were equal in a pair of the fracture surfaces. As compared with the scanning and transmission electoron fractographs taken from the same stretched zone, the same features in size were obtained from both fractographs.

(Received Nov. 19, 1979)

キ一・ワード：ステレオマッチング，ステレオ解析，ストレッチ・ゾーン，安定破壊
\end{abstract}

\section{1 緒言}

疲労き裂を有する試験片を静的に負荷したときに， き端先端の鈍化過程で作られるストレッチ・ゾーンの 幅 $(S Z W)$ の最大値は，材料の破壊じん性値と良い相 関があることが多くの材料によって得られて和り, そ の幅の測定にはフラクトグラフィが有効な手段として 活用されている。 また，ストレッチ・ゾーンはき裂の 開口の結果作られることから，ストレッチ・ゾーンの 高さ $(S Z H)$ の最大は，破壊が開始する際のき裂先端 の開口変位 (CTOD) を与兄ることが示されている. CTOD の測定には種々の方法が試みられているが， フラクトグラフィによる手法としては，予き裂面を電 子線の照射方向と同方向に置くことにより $S Z H$ を直 接観察する方法や，ステレオ解析による方法などがあ る. 前記したように, $S Z W$ については多くのデータ が集積されているので，もしも疲労予き裂面に対する $S Z W$ の傾斜角度 $\theta$ が定まれば, 破壊開始時の $S Z H=$ $1 / 2 C T O D$ が多くの材料について求まる可能性がある. すでに報告されている $\theta$ の值としては，アルミニウム 合金の場合 $15^{\circ}$ 以下, $35^{\circ}, 65^{\circ}, 70^{\circ}$, 鋼では $25 \sim 45^{\circ}$ 等の結果が示されて打り，かなりの範囲変化している

* 原稿受理 昭和54年11月19日

** 正会員 産業安全研究所 清瀬市梅園
が，これは材料特性と同時にき裂先端の力学条件に起 因すると推察される。なお，材料によってはストレッ チ領域の中央部以外からき裂が発生する場合もあり， このようなときには一対の破面で $\theta$ がかなり異ること も予想される。そこで本報では, フラクトグラフィの 手法を用いて $C T O D$ を求めるための手始めとして, 一対のストレッチ・ゾーンについてステレオマッチン グ解析を行い, ストレッチ・ゾーンの形状抏よび傾斜 角 $\theta$ について若干の検討を試みたので，その結果につ いて報告する.

\section{2 材料および実験方法}

供試材は, Table I に示す化学成分を有する SCM3 鋼であって，その熱処理条件拉よび機械的性質は， Table II に示すと抒りである.ここで Table II 中に 示す step cool は，焼もどしぜい化を起こさせること を目的として， $650^{\circ} \mathrm{C} て ゙$ 焼もぞし後，真空炉中で加熱 温度と時間を段階的に变克る以下の操作によった。

Table I. Chemical composition of the metarial used (wt. \%).

\begin{tabular}{c|c|c|c|c|c|c|c|c}
\hline $\mathrm{C}$ & $\mathrm{S} 1$ & $\mathrm{Mn}$ & $\mathrm{P}$ & $\mathrm{S}$ & $\mathrm{Ni}$ & $\mathrm{Cr}$ & $\mathrm{Mo}$ & $\mathrm{Cu}$ \\
\hline 0.36 & 0.20 & 0.82 & 0.013 & 0.007 & 0.04 & 1.10 & 0.16 & 0.03 \\
\hline
\end{tabular}


Table II. Heat treatments and mechanical properties of the material used.

\begin{tabular}{l|c|c|c}
\hline Heat treatments & $\begin{array}{c}\text { Yield stress } \\
\left(\mathrm{kg} / \mathrm{mm}^{2}\right)\end{array}$ & $\begin{array}{c}\text { U T.S. } \\
\left(\mathrm{kg} / \mathrm{mm}^{2}\right)\end{array}$ & $\begin{array}{c}\text { Elongation } \\
(\%)\end{array}$ \\
\hline Tempered at $650^{\circ} \mathrm{C}$ & 81.0 & 894 & 240 \\
Step cooled & 75.9 & 85.5 & 191 \\
\hline
\end{tabular}

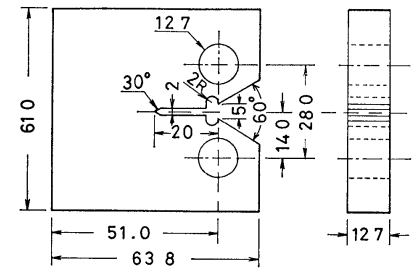

Fig. 1. Configuration of the compact fracture toughness specimen.

$650^{\circ} \mathrm{C}(1 \mathrm{~h}) \rightarrow 600^{\circ} \mathrm{C}(1 \mathrm{~h}) \rightarrow 550^{\circ} \mathrm{C}(15 \mathrm{~h}) \rightarrow 520^{\circ} \mathrm{C}(30$ h ) $\rightarrow 490^{\circ} \mathrm{C}(48 \mathrm{~h}) \rightarrow 470^{\circ} \mathrm{C}(72 \mathrm{~h}) \rightarrow$ 真空炉冷. 熱処 理後, ASTM 規格に準じて Fig. 1 に示すュンパクト 試験片を作成した．疲労予き裂は，電気油圧式疲労試 験機を用い，荷重比 $R$ を0.05として試験片幅 $W$ 亿対す るき裂長さ $a$ が 0.6 亿なるよらにき裂をそら入した。 試験は，中村らの方法と同様な $J_{\mathrm{I}}$ 試験を行った。す なわち，はじめに所定の変位まで静的に負荷後，一旦 負荷以前の変位まで除荷してから疲労によりき裂を伝 ぱさせた．この場合一部の試験については，2〜3 mm 程度疲労き裂が成長した後, 試験片を取りはずして板 厚中心で切断し，一方は破面観察に，他方は縱断面観 察に用いた。 $J$ 值は，荷重一荷重点変位曲線で囲まれ た面積Aを測定し， Rice の簡便式を用いて求めた.

$$
J=2 A / B b
$$

ここで， $B$ は試験片の厚さ， $b$ はリガメント幅であ る。

破面観察は，傾斜角度が $45^{\circ}$ まで可変できる走查電 子顕微鏡を用いて主に板厚中央について行ったが，一 部比較のために表面より $1 \mathrm{~mm}$ 内部の位置でも行った. また, 同一のストレッチ・ゾーンについて, 走査電顕 像と透過電顕像（レプリカ）の比較を行った，ステレ 才解析は，試料を $15^{\circ}$ または $30^{\circ}$ 傾斜させることによ り次式を用いて目的とする $S Z H$ を算出した。

$$
S Z H=l_{2} / \sin \alpha-l_{2} / \tan \alpha
$$

ここで, $l_{1}, l_{2}$ は Fig. 2 に示すように, 試料傾斜前 後の投影長さ， $\alpha$ は試料の傾斜角である.

このようなステレオ解析を行う場合，顕微鏡自身の 倍率やひずみによって精度が問題となるために，本報 ではあらかじめ 2000 特よび 3000 倍でマイクロビッ カースの圧痕についてステレオ解析を行い，誤差の程 度を確認するとともに，以後の解析に補正係数として 用いた。

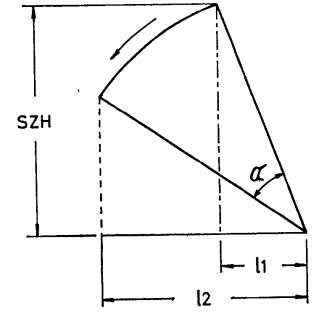

Fig. 2. Principle of stereo measurement.

\section{3 実験結果および考察}

\section{$3 \cdot 1650^{\circ} \mathrm{C}$ 焼もどし材}

Fig. 3 は, $S Z W$ とJの関係を示したもので, $S Z W$ は76. $4 \mu$ 程度で飽和して㐨り，飽和開始点に対応する $J$ 值は $16.7 \mathrm{~kg} / \mathrm{mm}$ となっている. この值は，有効 な $J_{\mathrm{Ic}}$ 試験の判定基準として提案されている次式を満 足しており， $J_{\text {Ic }}$ 值と判定される.

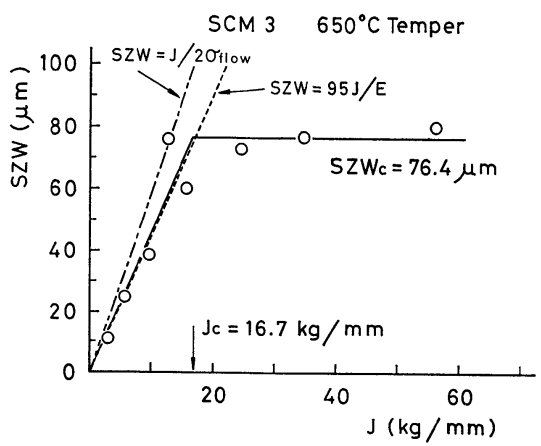

Fig. 3. Relationship between stretched zone width and $\mathrm{J}$-value.

$$
a, B, b \geqq \beta \cdot J_{\text {Ic }} / \sigma_{\text {flow }}
$$

ここで, $\sigma_{\text {flow }}$ は流動応力， $\beta$ は25 50とされてい る.な技， $S Z W$ が飽和する以前に括ける $S Z W$ と $J$ との関係は, 中村らの提案式 $S Z W=95 J / E$ によって ほぼ良く整理されるようである。

Fig. 4 は，J=3.5 kg/mm での板厚中央に和けるス トレッチ・ゾーンを示したもので, 一対の形状はスケ ッチに示すように，A側ではストレッチ部が複雑に変 化して拈り，ストレッチ・ゾーンの発生点も明確では ない，ステレオ解析の結果, 予き裂面の平均高さとス トレッチ・ゾーンの高さ $(S Z H)$ の差は約 $5.8 \mu$ であ って, もしも A 側の点線付近からストレッチングが生 じているのであれば $S Z W=8.3 \mu$ 程度, $\theta$ は $34.9^{\circ}$ と なる、な物，ストレッチングが明りょうな矢印間の長 さは約 $5 \mu$ であって， $\theta$ は $50^{\circ}$ 程度となっている。一 方，B側では形状が比較的明りょうであって，ストレ ッチ・ゾーンは予き裂面から高さがゆるやかに増加後, 急角度の壁面を形成している．この場合の $S Z H$ は約 $6.6 \mu$ 程度であって，図中の点線から測定したときの 


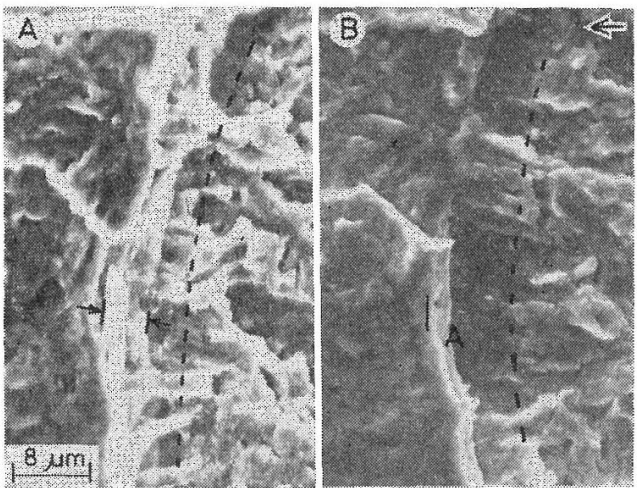

(a) Matching fractographs of stretched zone taken from Mid-thickness of the specimen tempered at $650^{\circ} \mathrm{C} . J=3.5 \mathrm{~kg} / \mathrm{mm}$.

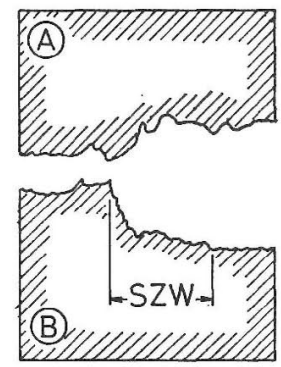

(b) Schematic illustration of the fracture surface contours.

Fig. 4. Matching fractographs and the profile of fracture surface.

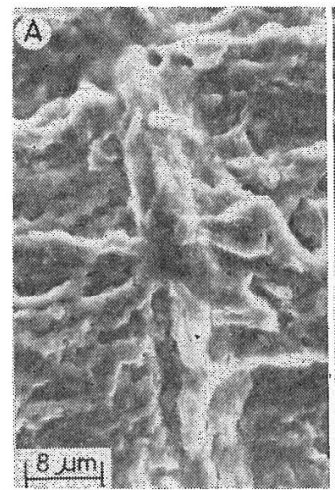

(a) Matching fractographs of stretched zone taken from near surface of the specimen. $J=3.5 \mathrm{~kg} / \mathrm{mm}$.

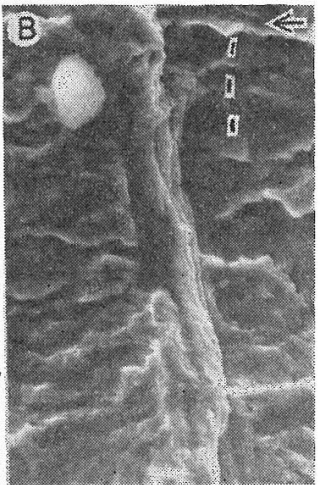

Fig. 5. Matching fractographs the profile of fracture surface.

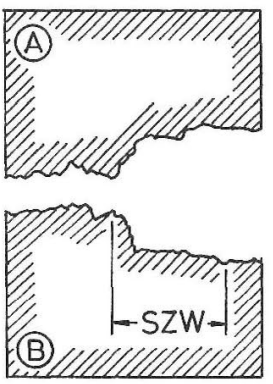

(b) Schematic illustration of the fracture surface contours.
SZW は約 $10.1 \mu$ であり， $\theta$ は $33.2^{\circ}$ 程度の值となる。 また、ストレッチングが最も激しく起っているA部か らの測定では， $\theta$ が $68.8^{\circ}$ 程度となっている。

Fig. 5 は，板厚方向に和けるストレッチ・ゾーンの 差異について検討するために，試験片表面より約 1 $\mathrm{mm}$ 内部に入った位監に和けるマッチング写真ととの スケッチを示したもので㐫る。この場合，A側の予き 裂面はかなり凹凹が激しく，ステレオ観察を行っても $S Z W$ を求めることは困難である.しかし，B側は比 較的斗らであって，带状に强くストレッチングされた 跡が観察され，文らに詳細に見ると，それ以後にる点 線で示す位置付近からストレッチングしている状態が わずかに認められる。ストレッチ・ゾーンの形状は， 板厚中央と同様, 傾斜のゆるやかな部分と急な面とか ら構成されて特り，緩斜面では蛇行すべりが電子線に 対してほぼ垂直になるために粗に見劣るのに齐し，急 斜面では蛇行すべりが重なるような状態となるので密 に見觉ると考えられる。このため，分解能が不足する ときには，疲労予き裂部とストレッテ・ゾーンの開始 点とが充分に識別できない可能性がある。な特，B側

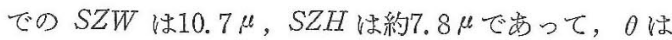
$36.1^{\circ}$ 程度になっている。ぬた，ストレッテングが明 りょらな急斜面の角度は約 $70^{\circ}$ とっってる。板厚中 央と表面より $1 \mathrm{~mm}$ 内部に和けるストレッチ・ゾーン を比較した場合，両者に大きな差異は見られない。乙 かし，さらに表面側では中央に比べて，SZW 就よ゙ $S Z H$ が減小する。

Fig. 6 は，J檤が増加した場合の結果を拡大写真と ともに示した斥ので，ストレッチ・ゾーンに隣接して ディンプルが形成されている。これらのディンプルの らも，大きなものは拡大写真に見られるように㴔㴽等 軸ディンプルとなっているのに対し，微小なディンプ ルでは引き裂き型となっている場合が多く認められる。 なお，大きなディンプルの側壁には，負荷時に生じた と思われる明りょらなストレッチングの跡が残されて いることから，この種のディンプルは，き裂先端の塑 性域中に存在する介在物が負荷過程で母材からはく離 し，その後新生面を作りながら成長したものと推察さ れる.Fig.7 は，前記のディンプル成長の状態をモデ ル的に示したものである. 佐藤らは，アルミニウム合 

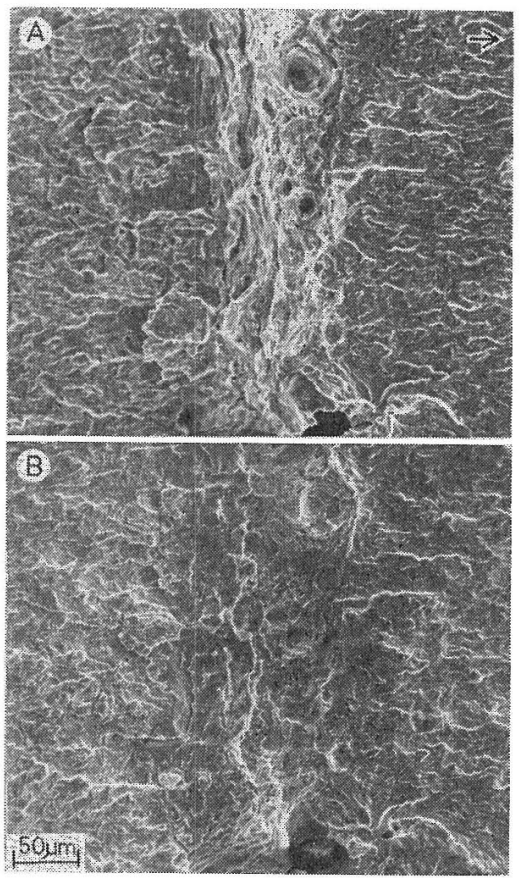

(a) Low magnification.
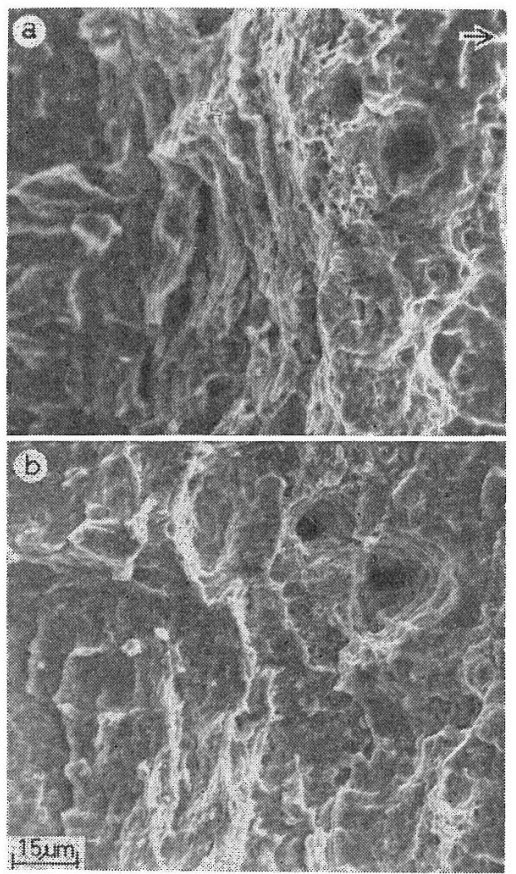

(b) Enlarged view of a part in Fig.6a. $J=12.6 \mathrm{~kg} / \mathrm{mm}$.

Fig. 6. Matching fractographs of stretched zone taken from the specimen loaded to high $\mathrm{J}$.value.

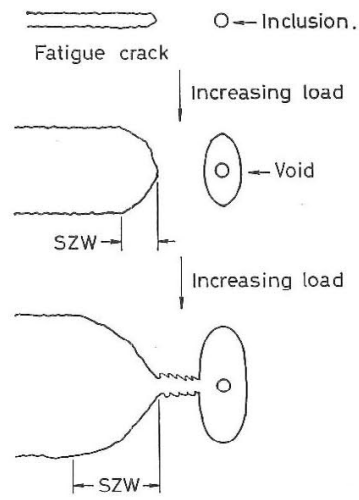

Fig. 7. Schematic illustration of void growth at crack tip.

金を用いて安定破壞を伴う場合の破壞じえ 性值に及ぼす介在物間隔を三つのモブルを 示して説明しているが，Fig.7 の結果は， 彼らのモデルのbタイプに相当する。つぎ に，安定破壞領域学除いた場合のストレッ チ・ゾーンの形状寸法について検討した結 果, $\mathrm{A}$ 側では $S Z W=110 \mu, S Z H=61.7 \mu て ゙$ 岁り， $\theta$ は $29.3^{\circ}$ 程度となっている。一方， $B$ 側では $S Z W=112.4 \mu, S Z H=21.6 \mu$ で 步り， $\theta$ は約 $10.9^{\circ}$ で峦って，一対で $\theta$ が

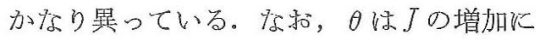
よって減小する場合が多いよらでむる。

\section{$3 \cdot 2$ ストレッチ・ゾーンの走查電顕像と透過電顕 像の比較}

Fig. 4 和よび 5 飞㜿いて，ストレッチ・ゾーンの発 生点がやや不明な場合が見られたが，走查電顕では分 解能の点から疲労破面の特徵的㥞相が明確に捕兄られ ず，したがって発生点を正磪に求めら孔ない可能性が 考克られる。そこで, Fig. 3 学得を破面からレプリカ を採取し，同一のストレッチ・ゾーンについて透過電 顕と走査電顕像の比較を行った. Fig. 8 は，その一例 を示したもので，透過電顕では予き裂面の特徴的形態 であるストライエーション状模様とストレッチングの 特徴である蛇行すべりの跡が比較的明りょらであって，

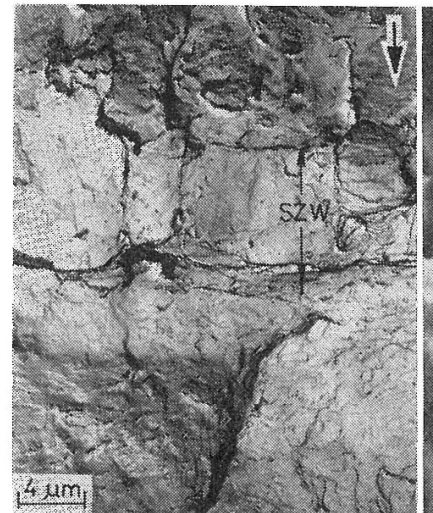

(a) TEM- fractograph.

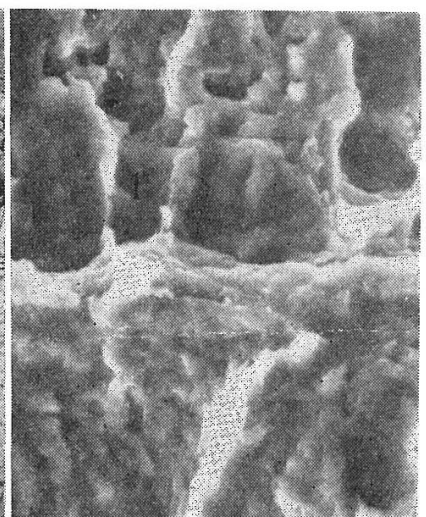

(b) SEM fractograph.
Fig. 8. Comparison between TEM and SEM fractographs obtained from the same area of the stretched zone. 


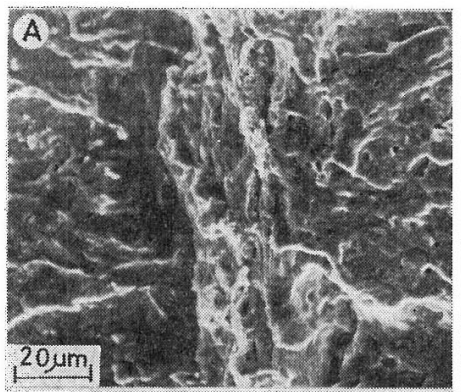

(a) Matching fractographs of stretched zone in the material step cooled.

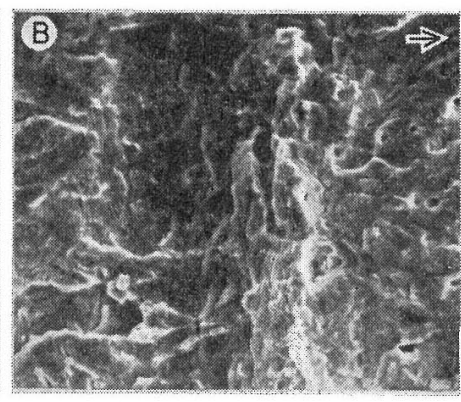

(b) Schematic illustration of the fracture surface contours. $J=11.4 \mathrm{~kg} / \mathrm{mm}$.

Fig. 9. Matching fractographs and the profile of fracture surface.

ストレッチ・ゾーンの発生点を容易に区別できるのに 対し, 走査電顕では1枚の写真からそれらの特徴を見 つけることはかなり困難である。な和，両写真につい て個及の形状寸法を比較した場合，旮れらはほぼ等し く, 分解能の点起除けば両者で本質的な差異はないよ らである、ストレッチ・ゾーン法により $J_{\text {I }}$ 值を求め る場合，SZW 分透過と走查電顕とでは若干異るとい う結果も見られるが，これは前述したよう火，走查電

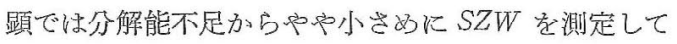
いるためではないかと推察される、以上は，安定破填 が介在しない場合の結果であって、ディンプルなどが 存在する場合でも，透過と走查電顕で同一寸法の像が 得られるかどうかは今後の検討を要する。

\section{$3 \cdot 3$ Step Cool 材}

Fig. 9 は, step cool 学行った試験片の結果を示し たもので，650゚埜もどし材の場合と同様，ストレッ チ・ゾーンは緩斜面と蛇行すべりが明りょらな急斜面 とから成っている。な拈, ストレッチ・ゾーンに隣接 して微小なディンプルが作られているが，これらは引

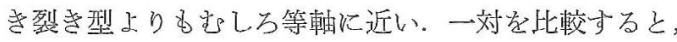
$S Z W$ は添滦等しいが，A側では明りょうな蛇行すべ りが広範车に見られるのに刘し，B側では顕著でない。 ステレオ観察の結果はスケッチに示すように，A側 の明りょらな蛇行すべり面は一部が大きく突き出して いるのに対し、B側ではゆるかな傾斜面となってい る. ステレオ解析の結果, $\mathrm{A}$ 側の $S Z W$ は $36.4 \mu$, $S Z H$ が約 $28 \mu, \theta$ が $37.6^{\circ}$ 程度で篎るのk対し，B 側は $S Z W$ が $35.6 \mu$, SZH が $10.4 \mu$ 程度, $\theta$ は約 16. $3^{\circ}$ となっており，一詨で $S Z W$ がほぼ同じで㐫っ ても，SZH が異るために，日にもかなりの差異が生 じている.

ストレッチ・ゾーンについて約20組のマッチングを 行いそのららの数列を示したが，いずれの場合にもと の形状は Fig. 10 に示すよらに, 緩斜面と急斜面とか らなっている．ストレッチ・ゾーンの傾斜角 $\theta$ は, 10 〜 48 程度香でのかなりのばらつきがあるために， $\theta$

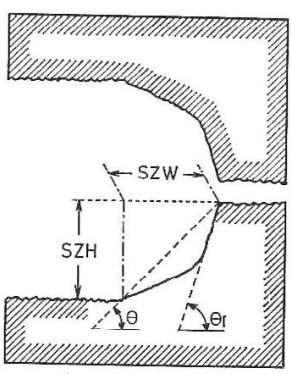

Fig. 10. Schematic profile of the stretched zone.

から一義的に CTOD を求わることは困難と思われる. な秎，統計的には报っていないが， $\theta$ は $33^{\circ}$ 程度の値 を取る場合が多いようである。采た，ストレッチング が顕著に起る角斜面の㞣度 $\theta_{\mathrm{I}}$ は, 比較的ばらつきが 少く, $60 \sim 70^{\circ}$ 程度の範囲に市る。

\section{4 結論}

SCM 3 鋼を用いて破筥じえ性試験を行い，ステレ オマッチングの手法を用いてストレッテ・ゾーンの形 状括与び傾斜角 $\theta$ について検討した結果定要約すれば， 以下の之频りで专る。

（1）ストレッチ・ゾーンの形状は，緩斜面と急斜面 の両面から構成されている.

（2）ストレッチ・ゾーンの傾斜角 $\theta$ は一定値をもた ず，10 $48^{\circ}$ 程度の広範囲汇渡って変化する。このう

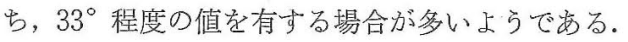

(3) 蛇行すべりが顕著な急斜面の角度 $\theta_{I}$ は $60 \sim 70^{\circ}$ 程度で就って，比較的ばらつきが少い。

(4) 両破面の $S Z W$ が同じでめっても，SZH は一対 で等しいとは限らない。

（5）同一のストレッチ・ゾーンについて走查電顕と 透過電顕像の比較を行った結果, 両者でその形状寸法 はほぼ等しく, 分解能の点を除けば観察方法による本 質的な差異は生じない。

特わりに，本報の使用材は材料学会フラクトグラフ 々部門委員会・組織と破壞小委員会の共同試験材で第 って，材料を提供された山陽特殊鋼の坪田一一氏，熱 
処理を担当された川崎重工の喜多清氏，富永昌武氏に 感謝の意を表します。

（昭和54年10月12日 第 2 回フラクトグラフィシンポシウムにて講演）

\section{参 考 文 献}

1) Spitzig, W. A., Trans. ASM, 61, 344 (1968).

2) Bates, R. C., and W. G. Clark, Jr., Trans. ASM, 62, 380 (1969).

3) Brothers, A. J., M. Hill, M. T. Parker, W. A. Spitzig, W. Wiebe, and U. E. Wolff, ASTM STP 493, 3 (1971).

4) Wolff, U.E., ASTM STP 493, 20 (1971).

5) Broek, D., Engng. Fract. Mech., 6, 173 (1974).

6）大塚昭夫, 宮田隆司, 西村誠二, 柏本陽一郎, 笠井 登, 造船学会論文集, 136, 249 (1974).

7）平野一美, 小林英男, 中村春夫, 中沢 一, 日本機械学 会講演論文集, 760-9, 151 (1976).

8) Kobayashi, H., K. Hirano, H. Nakamura, and H. Nakazawa, Proc. 4 th Inter. Conf. on Fracture, 3, 583 (1977).
9）大塚尚武, 上山秀雄, 中野正章, 日本機械学会講演論文 集, 780-9, 29 (1978).

10）大路清嗣, 小倉敬二, 内田秀紀, 藤本隆史, 日本機械学 会講演論文集, 780-12，196（1978）。

11）小林英男, 材料, 27, 711 (1978).

12）中村春夫, 小林英男, 中沢 一, 日本機械学会論文集, 45 (A), 336 (1979).

13) Landes, J. D., and J. A. Begley, ASTM STP 560, 170 (1974).

14）大塚尚武，日本機械学会 S781 分科会資料， No. 64 (1979).

15) Schwalbe, K., Engng. Fract. Mech., 6, 415 (1974).

16）佐藤邦彦，豊田政男，武藤睦治，西川修史，造船学会論 文集，144，303 (1978).

17) Rice, J. R., P. C. Paris, and J. G. Merkle, ASTM STP 536, 231 (1973).

18）西村秀雄, 高村仁一, 水曜会誌, 12, 118 (1952).

19）紀本静雄, 菅沼忠雄, 大島太市, 写真測量, 8, 8(1969).

20）佐藤 学, 小林英男, 中村春夫, 中沢 一, 日本機械学 会講演論文集， 790-12，238（1979）. 